\title{
Condition of South-Eastern Baltic Sea Shores and Methods of Protecting Them
}

\author{
Rafał Ostrowski*, Zbigniew Pruszak*, Alexander Babakov** \\ *Institute of Hydro-Engineering, Polish Academy of Sciences, ul. Kościerska 7, 80-328 Gdańsk, Poland, \\ e-mail: rafal.o@ibwpan.gda.pl, zbig@ibwpan.gda.pl \\ ** Institute of Oceanology of the Russian Academy of Sciences, Atlantic Branch in Kaliningrad (AB IO \\ RAS), Prospect Mira 1, 236000 Kaliningrad, Russia, e-mail: babakov_temp@mail.ru
}

(Received March 03, 2014; revised October 15, 2014)

\begin{abstract}
The paper describes lithodynamic and morphodynamic processes occurring in the main part of the south-eastern Baltic coastal area, namely on the sea shores from the Vistula mouth in the Gulf of Gdańsk to the Lithuanian-Latvian border. The study area is subject to intensive natural coastal changes, as well as shore evolution caused by anthropogenic impacts at several locations. Methods of coastal protection against erosion and shore stabilization systems applied in the past and currently are described. The paper deals with the causes of the dynamics of beach/dune shores and cliffs. It presents the authors' field observations of 2010-2013, as well as previously gained knowledge and the results of Polish, Russian and joint Polish-Russian field surveys.
\end{abstract}

Key words: South-Eastern Baltic coast, dynamics of cliffs and beach/dune shores, anthropogenic impacts, shore protection against erosion

\section{Introduction}

The sea shores from the mouth of the Vistula river to the Lithuanian-Latvian border can be regarded as representative of the main part of the south-eastern Baltic coast. This area comprises the coastal segment of the eastern part of the Gulf of Gdańsk, some of which lies in Poland and some in Russia (Kaliningrad Oblast), the shores of northern Sambia, the Curonian Spit (partly Russian and partly Lithuanian) and the remaining Lithuanian coast (north of the Klaipeda Strait), see Fig. 1. The coast under analysis has a compound configuration in which shoreline exposure changes several times from northward to westward. Moreover, strong anthropogenic impacts occur at four locations. The regional coastal processes display, aside from minor local effects, two points of distinct change in the directions of sediment fluxes, namely the convergence region near the Vistula Spit root and the divergence region at the Cape Taran. 


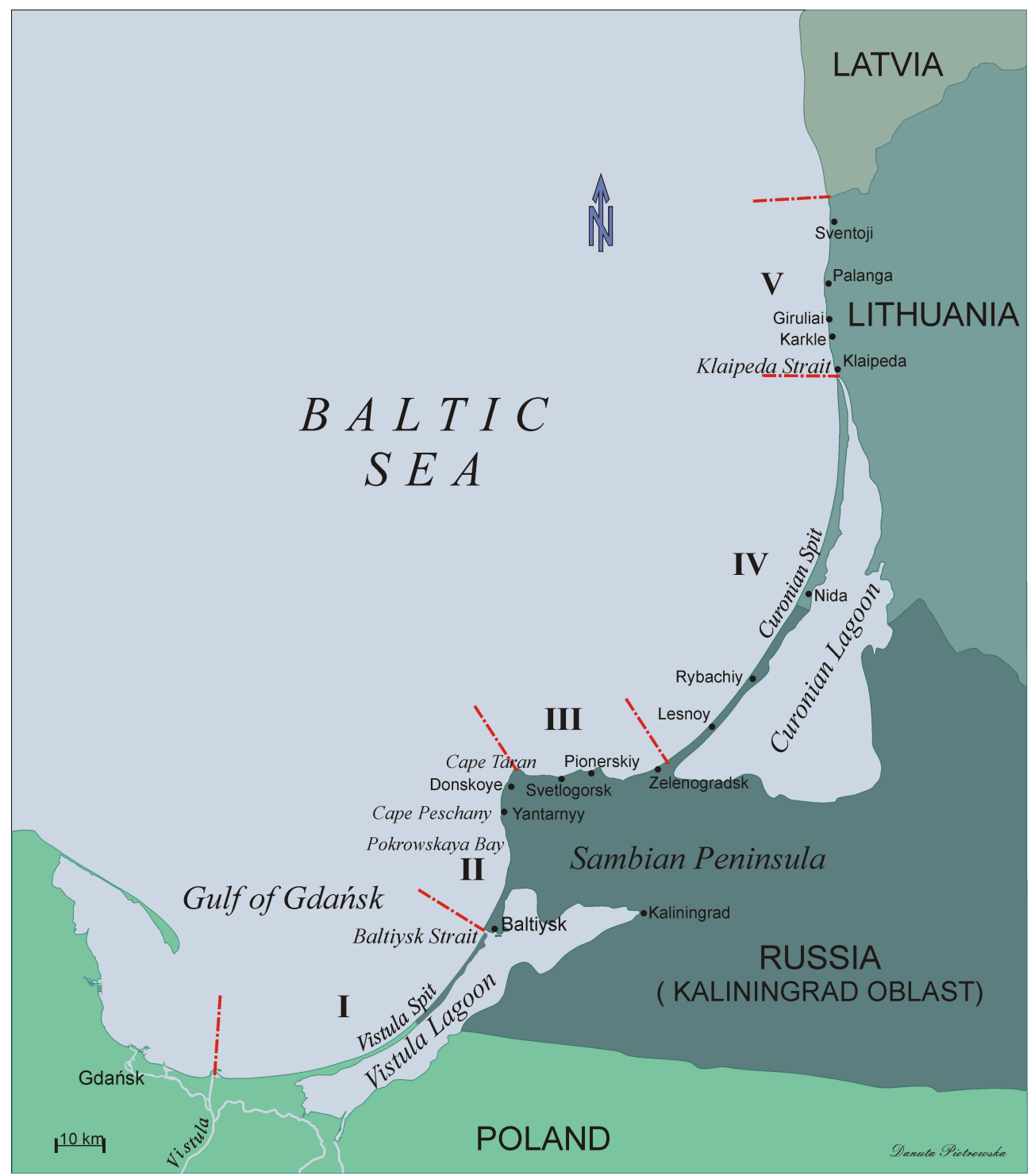

Fig. 1. Study area

In the study area, the Polish shore segment (from the Vistula mouth to the middle of the Vistula Spit) is $48 \mathrm{~km}$ long, the coastline in the Kaliningrad Oblast is 147 $\mathrm{km}$ long, and the length of the Lithuanian segment amounts to $95 \mathrm{~km}$. The coast discussed in the present paper is dominated by mildly sloped sandy shores. The study area comprises two long spits, namely the Vistula Spit (also known as the Baltiysk Spit) and the Curonian Spit, as well as a long stretch of a cliff-type coast. The cliff shore segments south of the Cape Taran (on the western coast of the Sambia Peninsula) are about $25 \mathrm{~km}$ long, $5 \mathrm{~km}$ of which are active cliffs (subject to abrasion). Active cliffs 
are the predominant type of sea shore on the northern coast of the Sambia Peninsula, from the Cape Taran to Zelenogradsk. The cliff-type coast stretches $30 \mathrm{~km}$ east of the Cape Taran, whereas a $5 \mathrm{~km}$ long shore segment west of Zelenogradsk constitutes an abrasive dune-type coast. The Lithuanian coast consists mostly of sandy dune shores. Some short cliff shore segments occur on the $45 \mathrm{~km}$ long coastal segment from the Klaipeda Strait to the Lithuanian-Latvian border.

Coastal spits are important morphological elements in the present study. The Vistula Spit is $55 \mathrm{~km}$ long, and the Curonian Spit is $99 \mathrm{~km}$ long. Taking into account morphological features and geographical layout, the coast under analysis has been divided into 5 regions. The first one $(73 \mathrm{~km}$ long) stretches from the Vistula mouth to the Baltiysk Strait (also called the Pilawa Strait); the second is the coastal segment from the Baltiysk Strait to the Cape Taran $(36 \mathrm{~km})$; the third, from the Cape Taran to the root of the Curonian Spit $(37 \mathrm{~km})$; the fourth, the entire sea shore of the Curonian Spit up to the southern breakwater of the Klaipeda harbour $(99 \mathrm{~km})$; and the fifth, from the northern breakwater of the Klaipeda harbour to the Lithuanian-Latvian border (45 km), Fig. 1.

\section{Materials and Methods}

Owing to the considerable environmental and geographical diversity of the southeastern Baltic shores, the analyses of physical processes occurring in the area were carried out separately for each of the five coastal regions. The assumed division made it possible to analyse hydro- and morphodynamic phenomena in each shore segment, constituting a roughly uniform coastal unit. The physical phenomena under analysis were studied in various time-spatial scales in close relationship with shore protection measures employed in particular coastal regions.

The analysis includes both recent data, from the authors' field observations of 2010-2013, and older archival materials.

The present study has two main objectives. The first is to present a concise analysis of basic morphodynamic processes occurring in the coastal segments under discussion and to assess the condition of these sea shores, their vulnerability to erosion, and local erosive threats. For the assessment of the local motions and budgets of sandy sediments, van Rijn's (1993) method has been chosen. This approach has also been adopted to determine whether a theoretical model of coastal lithodynamics is capable of reproducing physical processes observed in nature. The second objective is to review shore protection methods applied in particular coastal segments and to discuss their effectiveness. The synergy of the above two-directional investigations yields a complete, up-to-date depiction of lithodynamic processes on the south-eastern Baltic shores, their condition and protective measures employed in the face of current climatic changes and increasing anthropogenic pressure on coastal regions. 
The paper is based mostly on joint Polish-Russian field surveys and observations of coastal dynamics, as well as inspections of shore protection measures, carried out in recent years. These investigations were conducted as part of both national and international research projects. The study also draws on the results of numerous Polish, Russian and Lithuanian investigations published in various papers, conference proceedings and other materials.

To determine the pattern of longshore sediment fluxes in the area, the possible divergences and convergences of these fluxes, and sediment budgets, the computations of net annual longshore sediment transport rates were carried out for the five selected shore segments. The wave input was determined on the basis of the wave climate for 1958-2001, reconstructed by means of the WAM4 model and driven by meteorological (wind and air pressure) fields. For the reconstruction of Baltic waves, the model resolution of the spatial grid was $5^{\prime} \times 5^{\prime}$ (angular minutes). The model time step of the input wind data was set to 1 hour. At each grid point for every hour of the 44-year reconstruction period, computational results comprise the following representative wave parameters: significant wave height, wave period, and wave ray direction. The results of the wave climate reconstruction were used to determine offshore wave parameters for the five south-eastern Baltic coastal segments. The wave prognostic points were selected to represent waves at deep water (at least $20 \mathrm{~m}$ ), beyond the nearshore zone. It should be noted that long-term wave climate reconstruction by the WAM model has been widely applied in similar studies of Baltic shores, see e.g. Soomere et al (2013).

The nearshore wave-current parameters were determined by the classical model proposed by Battjes and Janssen (1978), as well as by a set of models developed by Szmytkiewicz (1996, 2002a, 2002b).

As already mentioned, one of the most commonly applied and acknowledged approaches, namely van Rijn's (1993) model, was used to compute longshore sediment transport rates. The bases of this model are presented below.

Van Rijn (1993) distinguishes between sediment transport below the reference height $a$, which is treated as bed-load transport, and sediment transport above the reference height, which is treated as suspended-load transport. Sediment is entrained in a water column by imposing a reference concentration at the reference height. Thus, the total transport consists of the bottom transport and the suspended transport:

$$
S=S_{b}+S_{s} \quad\left[\mathrm{~m}^{3} / \mathrm{m} / \mathrm{s}\right] .
$$

The bottom transport is given as:

$$
S_{b}=a V_{b} c_{a},
$$

where:

$a=$ thickness of the bottom transport layer,

$V_{b}=\frac{1}{\kappa}\left[-1+\ln \left(\frac{30 a}{r_{c}}\right)\right] V_{*, c}$, 


$$
\begin{aligned}
& c_{a}=0.015(\alpha) \frac{D_{50}}{a} \frac{T^{1.5}}{D_{*}^{0.3}}, \\
& V_{*, c}=\left(\frac{1}{8} f_{c}\right)^{1 / 2} V, \\
& D_{*}=D_{50}\left(\frac{\Delta g}{v^{2}}\right)^{1 / 3}, \\
& T=\frac{\tau_{b, c w}-\tau_{b, c r}}{\tau_{b, c r}}, \\
& \tau_{b, c w}=\mu_{c} \tau_{b, c}+\mu_{w} \tau_{b, w}=\left[\log \left(\frac{12 d}{r_{c}}\right) \log \left(\frac{12 d}{3 D_{90}}\right)\right]^{2} \frac{1}{8} \rho f_{c} V^{2}+\left(\frac{0.8}{D_{*}}\right) \frac{1}{4} \rho f_{w} U_{b}^{2}, \\
& \tau_{b, c r}=f\left(D_{*}, \Delta, g, D_{50}\right),
\end{aligned}
$$

in which the mean flow is represented by $V$, and the wave effect by $U_{b}$. The sediment and bottom characteristics are:

$$
\begin{aligned}
& D_{50}=50 \% \text { grain diameter (median grain diameter), } \\
& D_{90}=90 \% \text { grain diameter (median grain diameter), } \\
& \Delta \quad=\text { relative density of sand grains with respect to water density }\left(\Delta=\rho_{s} / \rho\right), \\
& r_{c}=\text { current-related bottom roughness }(0.5-1 \text { times ripple height), } \\
& r_{w} \quad=\text { wave-related bottom roughness ( } 2-3 \text { times ripple height). }
\end{aligned}
$$

From these parameters the following bottom parameters are derived:

$$
\begin{gathered}
f_{c}=0.24\left[\log \left(\frac{12 d}{r_{c}}\right)\right]^{-2}, \\
f_{w}=\exp \left(-6.0+5.2\left(\frac{U_{b}}{\omega r_{w}}\right)\right)^{-0.2}, \quad \text { with } f_{w} \leq 0.3 .
\end{gathered}
$$

The suspended transport is given as:

$$
S_{s}=\left(F_{c}+F_{w}\right) V d c_{a},
$$

where $d$ denotes water depth, whereas $F_{c}$ and $F_{w}$ are correction factors for currents and waves, respectively:

$$
F_{c}=\frac{\left[\left(\frac{a}{d}\right)^{z_{c}}-\left(\frac{a}{d}\right)^{1.2}\right]}{\left[\left(1-\frac{a}{d}\right)^{z . c}\left(1.2-z_{c}\right)\right]},
$$




$$
F_{w}=\frac{\left[\left(\frac{a}{d}\right)^{z_{w}}-\left(\frac{a}{d}\right)^{1.2}\right]}{\left[\left(1-\frac{a}{d}\right)^{z . w}\left(1.2-z_{w}\right)\right]}
$$

with:

$$
\begin{gathered}
z_{c}=\frac{W}{\kappa U_{*, c}}, \\
z_{w}=50\left(\frac{U_{b}}{\omega}\right)^{-0.8}\left(\frac{H_{s}}{d}\right)^{0.1}\left(\frac{U_{b}}{V}\right)^{0.1}\left(D_{*}\right)^{-0.7},
\end{gathered}
$$

where $W$ denotes fall velocity of grains.

The results of sediment transport calculations, e.g. the identification of locations at which longshore sand fluxes converge or diverge, have been useful in explaining many coastal morphodynamic effects. In brief, the modelling of sediment motions and budgets has confirmed the usefulness of van Rijn's (1993) method as a tool for describing complex coastal lithodynamic phenomena, even in large time-spatial scales.

\section{Vistula Spit (Region 1)}

From the geo-morphological point of view, the approximately $18 \mathrm{~km}$ long stretch of coast from the Vistula mouth to the root of the Vistula Spit (Fig. 1) is also a spit. This spit has the form of wide and high densely forested dunes, separating the Vistula delta plain from the sea. The Vistula delta plain is a lowland, $47 \%$ of which has the ordinates of $0-5 \mathrm{~m}$ above the mean sea level and $28 \%$ is depressive (with the minimum ordinate of about $-1.8 \mathrm{~m})$.

The Vistula Spit (both the abovementioned segment and the spit proper, from its root to the Baltiysk Strait) is built entirely of sandy sediments. Grain sizes are variable along the spit, with the median diameter $d_{50}=0.18-0.31 \mathrm{~mm}$ south-west of the Baltiysk Strait, $d_{50}=0.16-0.23 \mathrm{~mm}$ in the region of the Polish-Russian border (Babakov et al 2010) and 0.19-0.24 mm in the remaining (Polish) part of the Vistula Spit (Ostrowski et al 2012). According to our observations, large amounts of sandy sediments in the nearshore zone of the Vistula Spit favour the occurrence of up to three bars. They are located at distances of 20-70 m, 130-200 m and 300-450 $\mathrm{m}$ from the shoreline. The presence of the bars, wide beaches (30-40 $\mathrm{m}$ on average) and dunes (50-100 m) explains the high resistance of the Vistula Spit shores to storm erosion (Dubrawski, Zawadzka-Kahlau 2006).

The resultant longshore sediment transport is directed from north-east to southwest, and according to Ostrowski et al (2010), has a net rate of 50 000-60 $000 \mathrm{~m}^{3} / \mathrm{year}$ near Baltiysk. This rate decreases along the Vistula Spit, and the direction of longshore sediment transport is reversed near the root of the Visula Spit, which thus constitutes a convergence point (Ostrowski et al 2010). Similar directions of sediment transport vectors are presented by Musielak (1980), who suggests that longshore sediment 


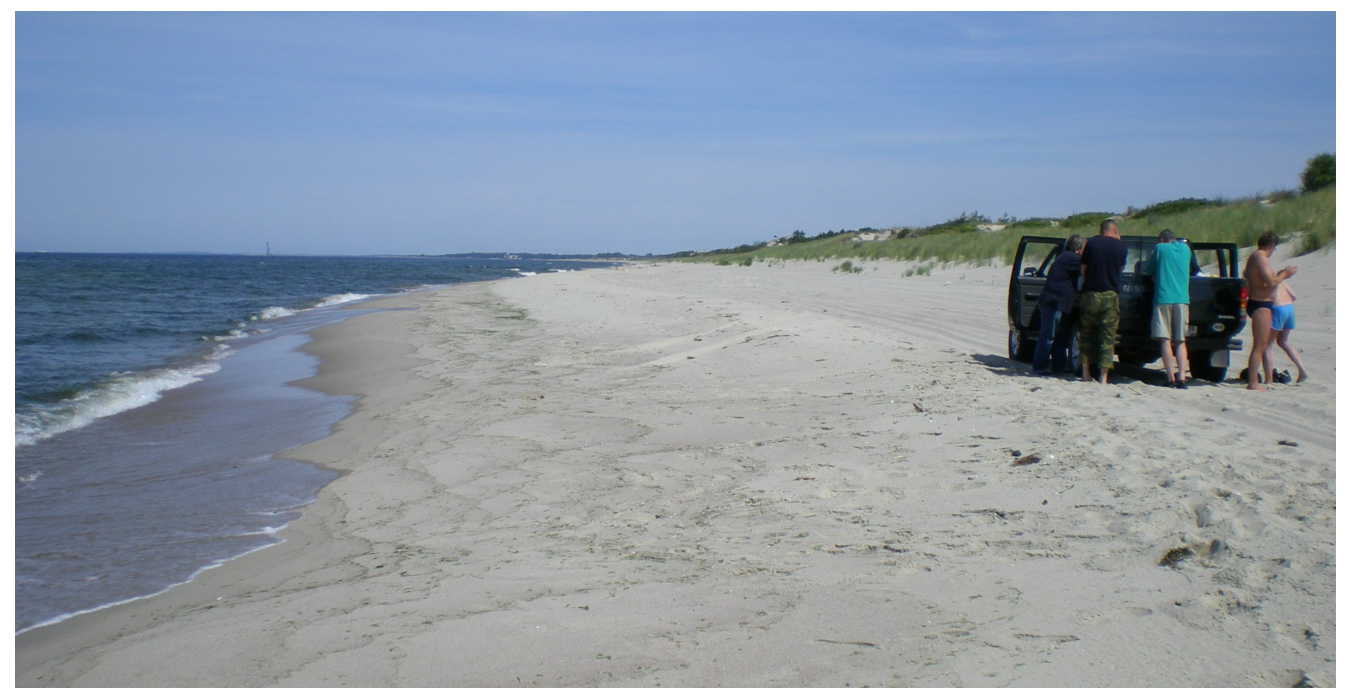

Fig. 2. Vistula Spit sea shore at a distance of about $10 \mathrm{~km}$ from the Baltiysk Strait

fluxes converge near the Vistula Spit end, close to Baltiysk. Breakwaters (also called moles, piers or jetties) in the Baltiysk Strait are a serious obstacle to the longshore sediment flux, and therefore cause persistent erosion on the lee side, south-west of the strait (Chechko et al 2008). This negative impact of breakwaters extends over 4-7 km south-west of the Baltiysk Strait, resulting in an erosion rate of 0.4-0.7 m/year (Ostrowski et al 2012). In close vicinity of the Baltiysk Strait (ca. $800 \mathrm{~m}$ from the southern breakwater) the erosion rate can be as high as $3 \mathrm{~m} /$ year (Bobykina, Karmanov 2009). Further south-west of the strait (more than about $7 \mathrm{~km}$ ), the sea shore becomes stable or accumulative (Fig. 2). According to Bobykina and Karmanov (2009), the accumulation rate in the central part of the Vistula Spit (near the Polish-Russian border) is locally up to $0.5-1.0 \mathrm{~m} /$ year. This is in agreement with earlier observations of Zawadzka-Kahlau (1999), who identifies the Vistula Spit coast as one of few Polish shore segments displaying features of morphological stability, with prevailing accumulative processes. The predominance of these processes in the region of the Vistula Spit, together with weak effects of sediment flux convergence, results in local coastal changes of $0.5 \mathrm{~m} /$ year at the maximum, from -0.2 to $+0.4 \mathrm{~m} /$ year on average (Zawadzka-Kahlau 2012). It should be pointed out that the evolution of the Polish part of the Vistula Spit is the least noticeable at its root and the most intensive near the Polish-Russian border.

As a result of decreasing longshore sediment transport rates from the Russian-Polish border to the Vistula river mouth and the convergence of longshore sediment fluxes at the Vistula Spit root, coastal accumulation prevails, while erosive processes are weak and generally local. It is worth noting that the hinterland of dunes is almost totally undeveloped and unused for tourist purposes. Hence there is no need for shore protection against erosion and flooding. 


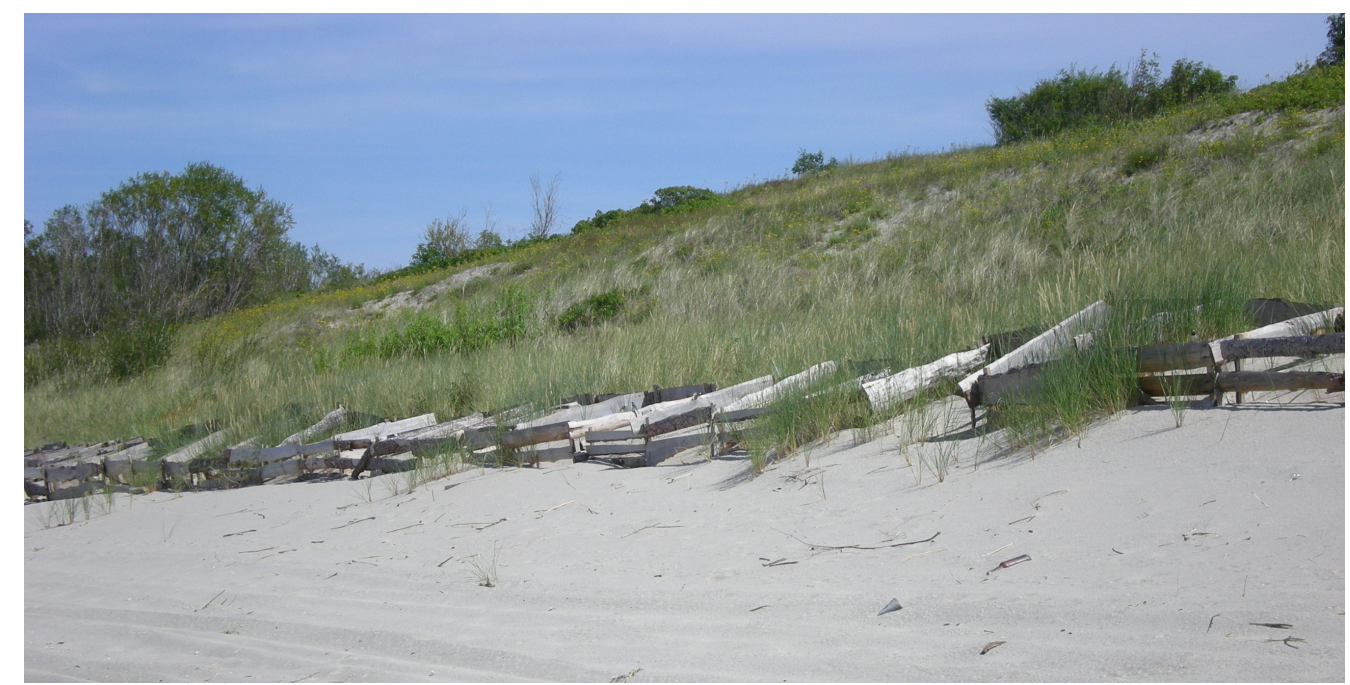

Fig. 3. Light wooden sand-accumulation structures built at the dune toe in the Russian coastal segment of the Vistula Spit in 1976

Light small wooden structures (looking like cages or boxes), placed locally at the dune toe, are the only technical shore protection measure applied in the Russian coastal segment of the Vistula Spit (Fig. 3). On the Polish side of the border, light sand-accumulation structures are built as fences of wooden sticks. These protective elements help to stabilize sand at the landward edge of the beach and accelerate dune accretion, which increases the resilience of the shore to erosion during storms. Aside from these "soft" engineering interventions, there are no other interventions affecting the natural coastal processes on the Vistula Spit.

The only exception are occasional nourishment operations near the Kosa village, located on the Vistula Spit just south-west of the Baltiysk Strait. Separated from the sea by a narrow beach and a low-crested dune system, the village is vulnerable to flooding during extreme storm surges. In order to remedy this situation, sporadic nourishment operations are carried out by dumping sediment in the nearshore zone, a few hundred metres from the shoreline. The material is obtained from dredging works on the waterway from the Baltiysk Strait to the Kaliningrad harbour.

\section{Baltiysk Strait - Cape Taran (Region 2)}

The beaches of this coastal segment are built mostly of well-sorted sediments $\left(S_{0}=\right.$ $1.25-1.5$ ) having the median grain diameter $d_{50}=0.24-0.31 \mathrm{~mm}$ (Babakov 2010). Finer fractions occur in the submerged part of the sea bed cross-shore profile, except for the regions close to the Cape Taran and the Baltiysk Strait, where coarser sand is found in the nearshore sea bottom. Sediments having the largest grain sizes occur in the region of Donskoye and the Cape Taran, while finer sandy material is found 5-10 $\mathrm{km}$ north of the Baltiysk Strait. 
The steepness of the sea bed cross-shore profile, which depends on grain sizes, is the highest near the Cape Taran and Donskoye, where it amounts to 0.025-0.035. According to Babakov (2010), a much lower steepness of the nearshore sea bottom, equal to about 0.008 , is observed along the shore segment stretching from Yantarnyy to the Baltiysk Strait (locally near the Baltiysk Strait it grows to 0.009-0.012). Such a mild inclination of the nearshore sea bed results from the very intensive long-term discharge of water-soil mixture by an amber mining plant located on land in Yantarnyy.

Coastal processes in this region are very complex, driven by both natural conditions (longshore sediment transport to the south from the divergence point at the Cape Taran) and anthropogenic impacts, namely the breakwaters in Baltiysk and the past discharge of huge sand volumes from the Yantarnyy Amber Mining Plant. Sokolov and Chubarenko (2012) proved a considerable wind influence on the formation of nearshore currents in this region. Remote-sensing observations in the south-eastern Baltic confirm the complicated hydrodynamics of this area and reveal coastal sub-mesoscale eddies, related to the predominant western storm winds, which affect the coastline perpendicularly (Gurova, Chubarenko 2012).

Amber mining and the production of sandy waste in Yantarnyy started in 1880. After 1958, this discharge increased significantly, leading to the development of huge coastal accumulative forms, such as vast shoals and areas of land accretion. According to various sources, the total discharge at Yantarnyy has yielded a sand volume from 85 million $\mathrm{m}^{3}$ (Boldyrev 1999) to 107 million $\mathrm{m}^{3}$ (Bass, Zhindarev 2007). In the period from 1963 to 1989, the discharge amounted to 2-3 million $\mathrm{m}^{3} /$ year, whereas in recent years it has been significanly lower than $100000 \mathrm{~m}^{3} /$ year.

There is only one underwater bar between the Baltiysk Strait and the Cape Taran. Two bars, exceptionally, occur in the region of Yantarnyy. A considerable reduction of sand discharge in the 1990s slowed down shore accretion in Yantarnyy and south of this village. For instance, the accumulation rate just north of the Baltiysk Strait decreased from $990000 \mathrm{~m}^{3} /$ year to $490000 \mathrm{~m}^{3} /$ year.

The results of the modelling of net sediment transport rates by Ostrowski et al (2010) show that the resultant sediment flux is directed from the Cape Taran towards the Vistula Spit. The maximum net rate of this flux was obtained in the region of Yantarnyy (about $312000 \mathrm{~m}^{3} /$ year). Net sediment transport rates decrease gradually in the south-western direction and are almost zero at the root of the Vistula Spit.

After the intensification of amber mining by the plant, the originally eroded cliff shore near Yantarnyy became accumulative, with an accretion rate of 25-30 m/year. The most significant accumulation was observed in the Pokrowskaya Bay (Fig. 4). In the period from 1958 to 1989, the maximal shoreline advance just north of Yantarnyy and in the Pokrowskaya Bay (south of Yantarnyy) was $800 \mathrm{~m}$ and $700 \mathrm{~m}$, respectively. In the same period, the beach area increased by $4700000 \mathrm{~m}^{2}$ (Boldyrev et al 1992). 


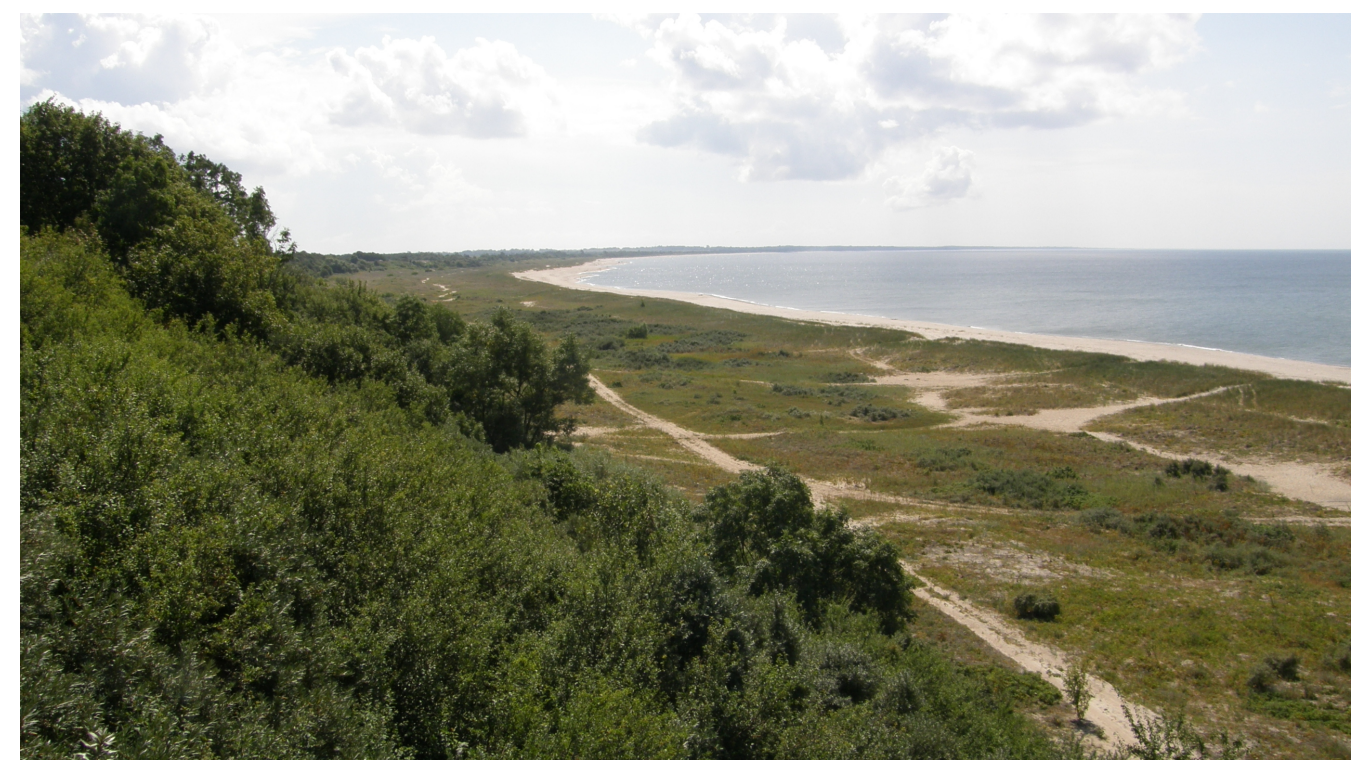

Fig. 4. Sediment accumulation in the Pokrowskaya Bay, resulting from the discharge of sandy sediments by the Yantarnyy Amber Mining Plant

North of Yantarnyy, the long-term discharge of sandy sediments has led to the appearance of vast accumulative areas with coastal lakes, which are presently used for recreation purposes (Fig. 5).

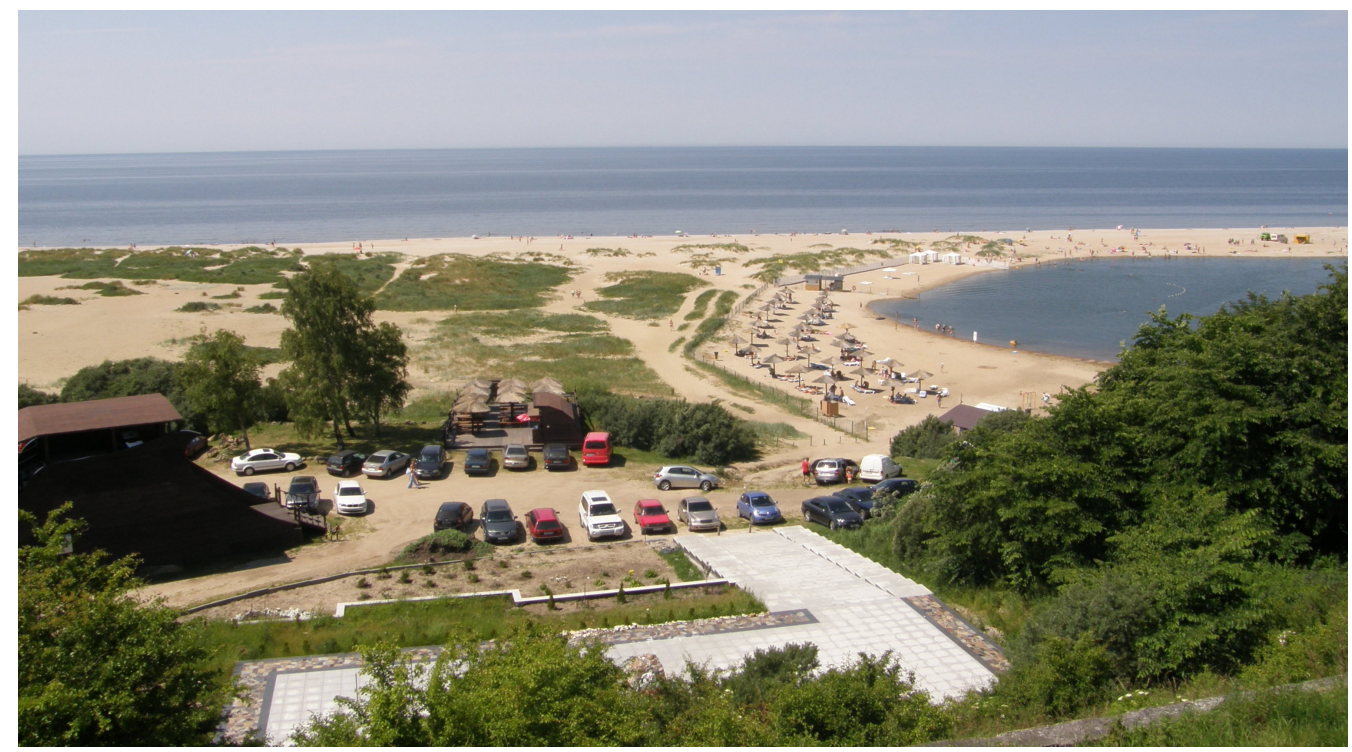

Fig. 5. Recreation area on a wide accumulated beach shore at the cliff foot near Yantarnyy 
After a considerable reduction in sediment discharge, erosive processes appeared, locally reaching a rate of $15-20 \mathrm{~m} /$ year. Observations carried out on the shores of the Pokrowskaya Bay in 2007-2008 revealed an erosion rate of about $5 \mathrm{~m} / \mathrm{year}$, while in the region of the Cape Peschany and at some other locations this rate amounted to about $2 \mathrm{~m}$ /year (Bobykina, Karmanov 2009; Burnashov et al 2010). The beach in this area is 30-100 $\mathrm{m}$ wide (Burnashov et al 2010). In the period from 2002 to 2007, the maximum erosion, of up to $20 \mathrm{~m} /$ year, was recorded north of Yantarnyy (Bobykina, Karmanov 2009). The beach in Yantarnyy is 20-70 m wide (Burnashov et al 2010). According to Burnashov et al (2010), nourishment at a rate of about $250000 \mathrm{~m}^{3} /$ year is necessary to mitigate erosion and to stabilise the shore in the region.

In the past, the discharge of sediment from the amber mining plant positively affected the sea shore in the entire span from the Baltiysk Strait to the Cape Taran, and there was no need for any protective measures on the western coast of the Sambia Peninsula. Because of this, a groin near Donskoye is the only shore protection structure on this coast. The groin was constructed to protect the outlet of a wastewater pipeline. It is damaged in its root part, and therefore seems to be not fully effective (Fig. 6).

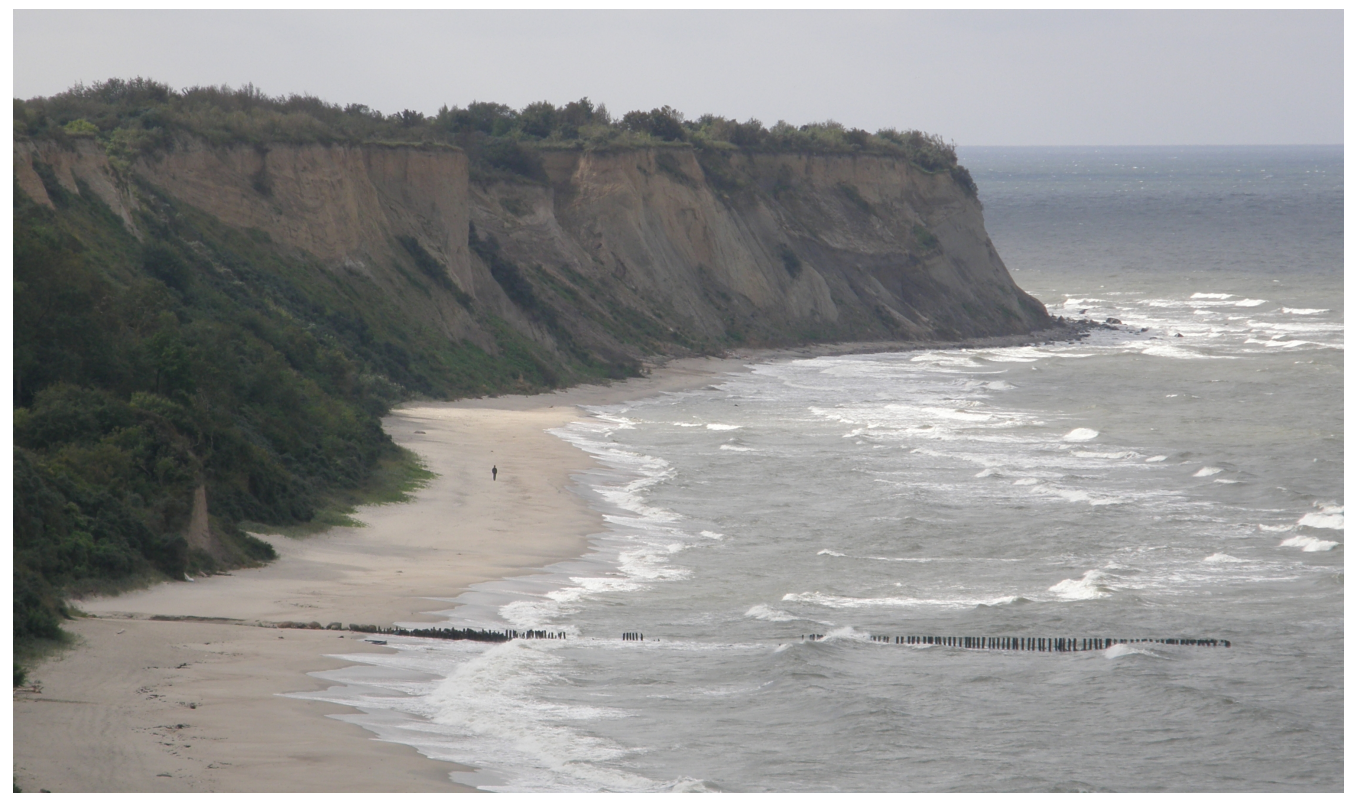

Fig. 6. The single groin near Donskoye (northern part of the western coast of the Sambia Peninsula) constructed in 1938 for protection of the wastewater pipeline outlet 


\section{Cape Taran - root of the Curonian Spit (region 3)}

Beach sediments occurring in this shore segment have the median grain diameter $d_{50}=0.15-0.20 \mathrm{~mm}$. Coarser material, including pebbles, can be found at headlands and promontories. There are generally no bars on the coast from the Cape Taran to the root of the Curonian Spit. The sediment flux is directed eastwards. Its rate increases with the distance from the Cape Taran up to about $200000 \mathrm{~m}^{3} /$ year near Svetlogorsk (Babakov 2003). The sea shore at most of its length is subject to heavy erosion (Fig. 7 ) and retreats at a mean speed of $0.5-0.8 \mathrm{~m} /$ year.

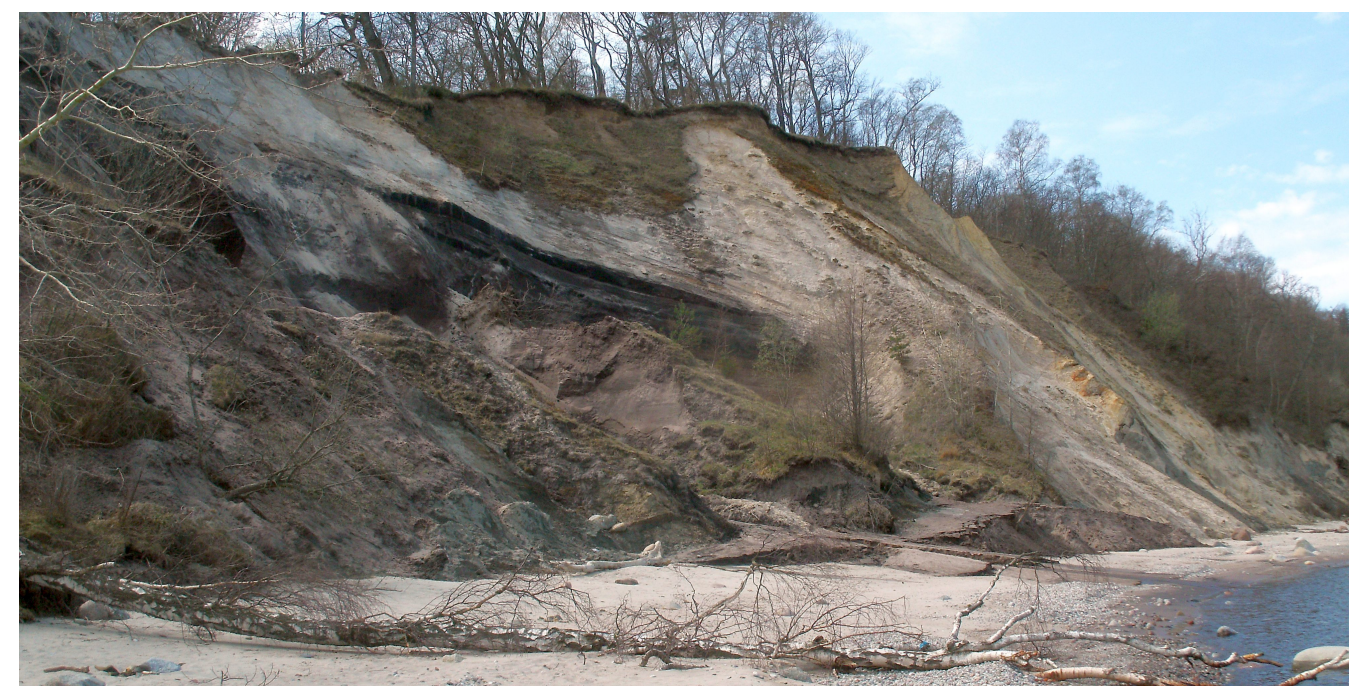

Fig. 7. Coastal erosion between the Cape Taran and Svetlogorsk

This erosion is a serious problem to the tourist resorts of Svetlogorsk, Pionerskiy and Zelenogradsk. Therefore, new shore protection measures have recently been implemented. Gabion revetments have been constructed $500 \mathrm{~m}$ west and east of the centre of Svetlogorsk (Fig. 8), whereas an approximately $1.6 \mathrm{~km}$ long permeable protective structure with a wide pavement on its top has been built in Pionerskiy (Fig. 9). The new structures were built at the sites of old ones, destroyed or malfunctioning. However, there are still some shore segments equipped with old, damaged seawalls and groins (Fig. 10).

The coast from the Cape Taran to the root of the Curonian Spit is dominated by heavily eroded cliff-type shores. The only coastal system with a foredune stretches over about $5 \mathrm{~km}$ west of Zelenogradsk. Similarly to cliff segments on the northern Sambia coast, this dune-type shore is subject to erosion, especially during heavy storms. 


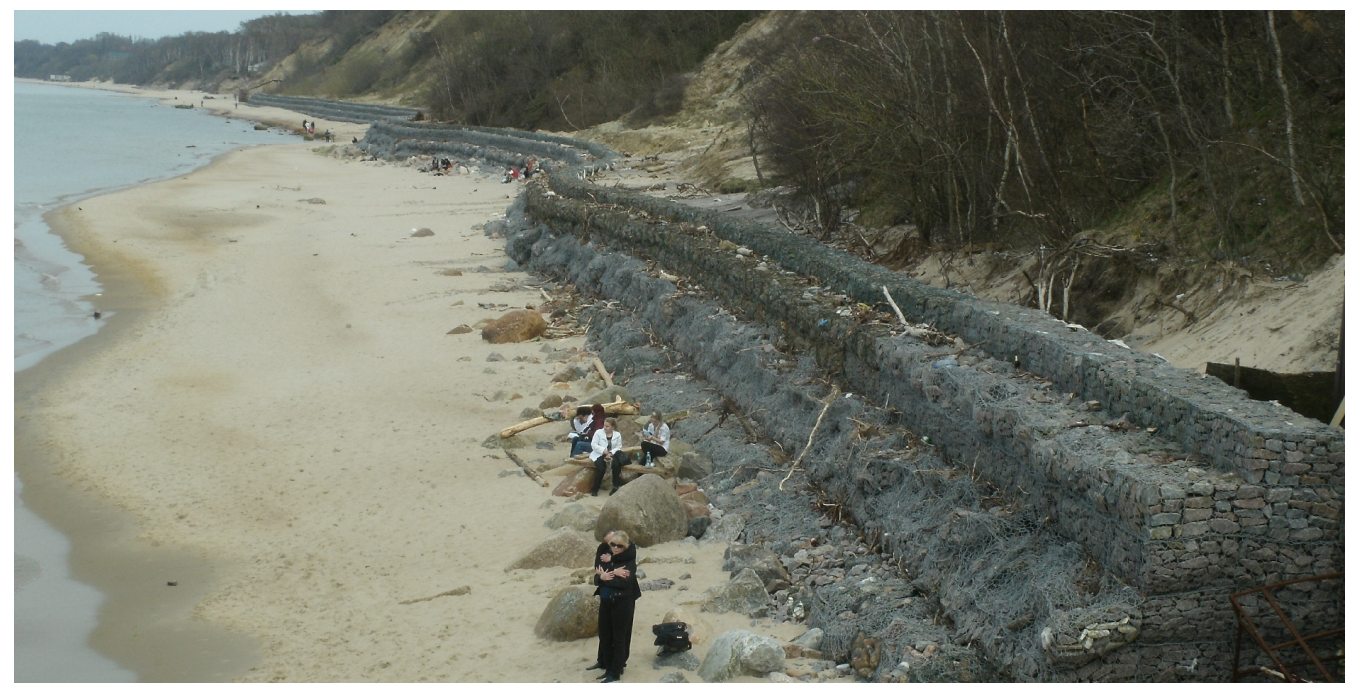

Fig. 8. Gabion structures near Svetlogorsk built in 2009

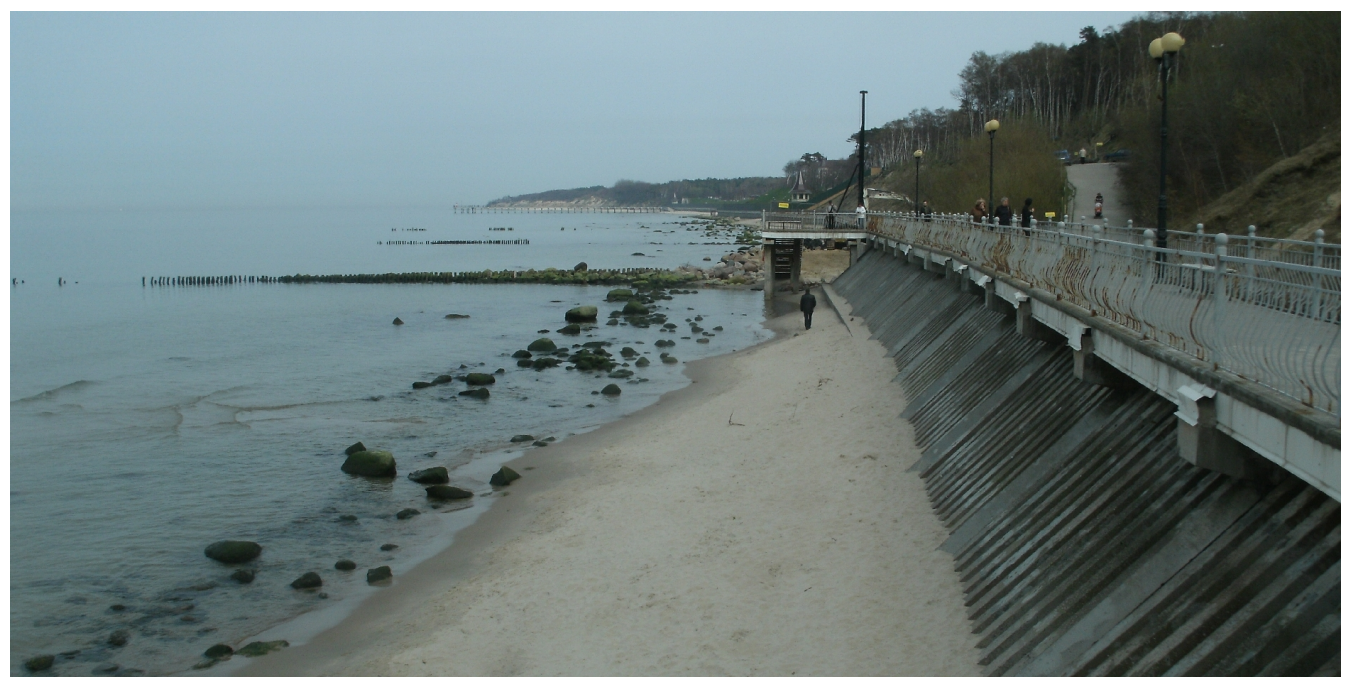

Fig. 9. A massive permeable revetment with pavement on top in Pionerskiy, built in 2008 (570 $\mathrm{m}$ long) and extended by $1 \mathrm{~km}$ eastwards in 2011

\section{Root of the Curonian Spit - Klaipeda southern breakwater (region 4)}

A two-bar system prevails along the coast of the Curonian Spit (Gelumbauskajte 2003). The first bar lies at a distance of about 100-150 $\mathrm{m}$ from the shoreline, whereas the second is located about $300-500 \mathrm{~m}$ from the shoreline. Sometimes, the third bar is observed. In such a case, the bar zone is also up to $500 \mathrm{~m}$ wide. The nearshore sea bottom has an inclination of $0.01-0.015$. In the region from Zelenogradsk to Lesnoy $(12 \mathrm{~km})$, sand with $d_{50}=0.3-0.4 \mathrm{~mm}$ predominates on the beach and in the dunes, 


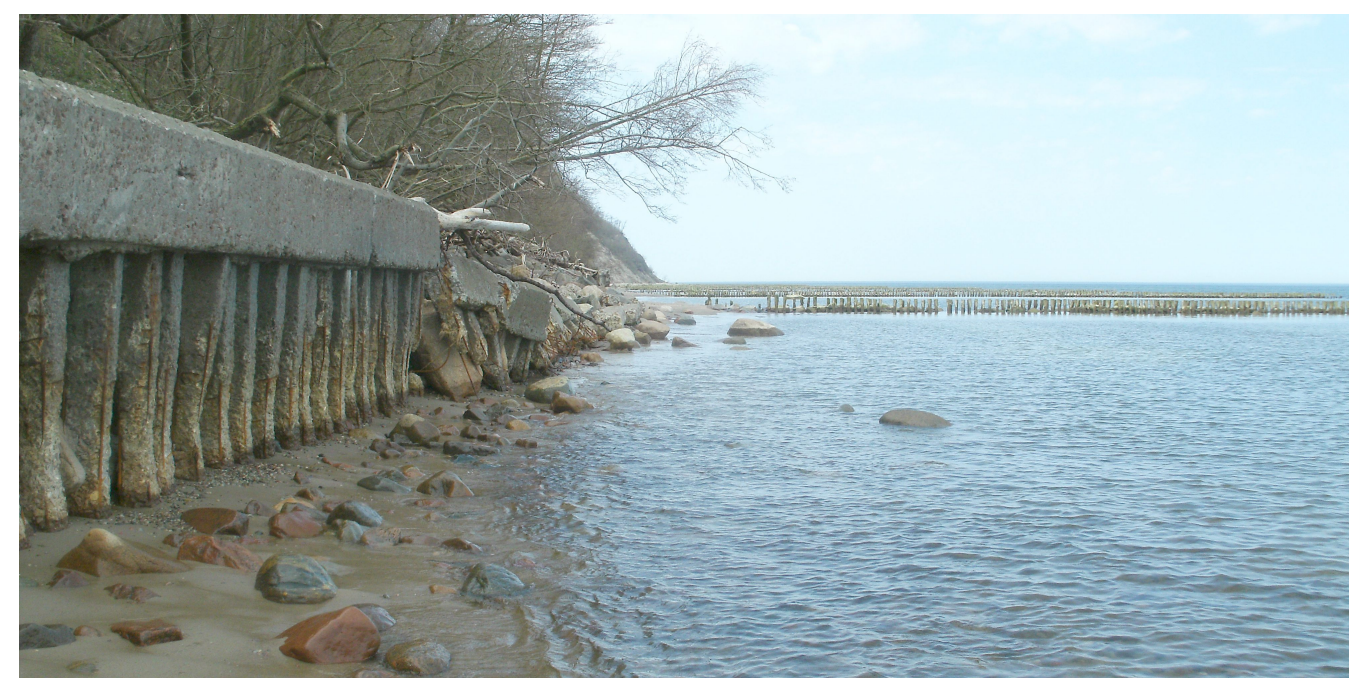

Fig. 10. Damaged shore protection structures west of Svetlogorsk (near the Otradnoye village), $900 \mathrm{~m}$ long, built in 1966

whereas pebbles occur near the shoreline. Farther north-eastwards and northwards, namely near Rybachiy (Russia) and Nida (Lithuania) up to Klaipeda, sediments on the Curonian Spit consist of sand only, having the median grain diameter $d_{50} \approx 0.2-0.3$ $\mathrm{mm}$.

The first part of the Curonian Spit (15 km long) is an erosive shore, with the maximum shoreline retreat rate of $1.25 \mathrm{~m} /$ year (Burnashov 2011). The most severe erosion takes place in a shore segment at the root of the Curonian Spit (1-2 km). Here, intensive dune abrasion and retreat were observed during heavy storms in 1990, 1991, 1997 and 1999. The most catastrophic erosive event took place in 1983, when the dune system was locally breached, and sea water flowed into the Curonian Lagoon (Orlenok 2004).

Very few shore protection measures have been applied on the Curonian Spit. There are old palisade groins east of Zelenogradsk and a new $120 \mathrm{~m}$ long massive permeable revetment in Lesnoy (Fig. 11). This revetment is equipped with inner wave energy dissipaters constructed of concrete elements and tyres. The wave energy dissipaters of this type stretch beyond the permeable revetment, about 340 m north-eastwards.

At a distance of $12-15 \mathrm{~km}$ from the Curonian Spit root, coastal erosion rates decrease to zero. In addition to the first sandy bar, located 150-200 $\mathrm{m}$ from the shoreline, there is the second bar at a distance of 400-600 $\mathrm{m}$ from the shoreline. The mean beach width amounts to about $40 \mathrm{~m}$.

Further north-eastwards, up to Rybachiy ( $32 \mathrm{~km}$ from the Curonian Spit root), the shore becomes stable ("transitional" in the lithodynamic "sense"). North of Rybachiy, accumulation definitely predominates, with a shore accretion rate of $0.3-0.7 \mathrm{~m} /$ year. The beach width gradually increases, up to about $50 \mathrm{~m}$ at the Russian-Lithuanian 


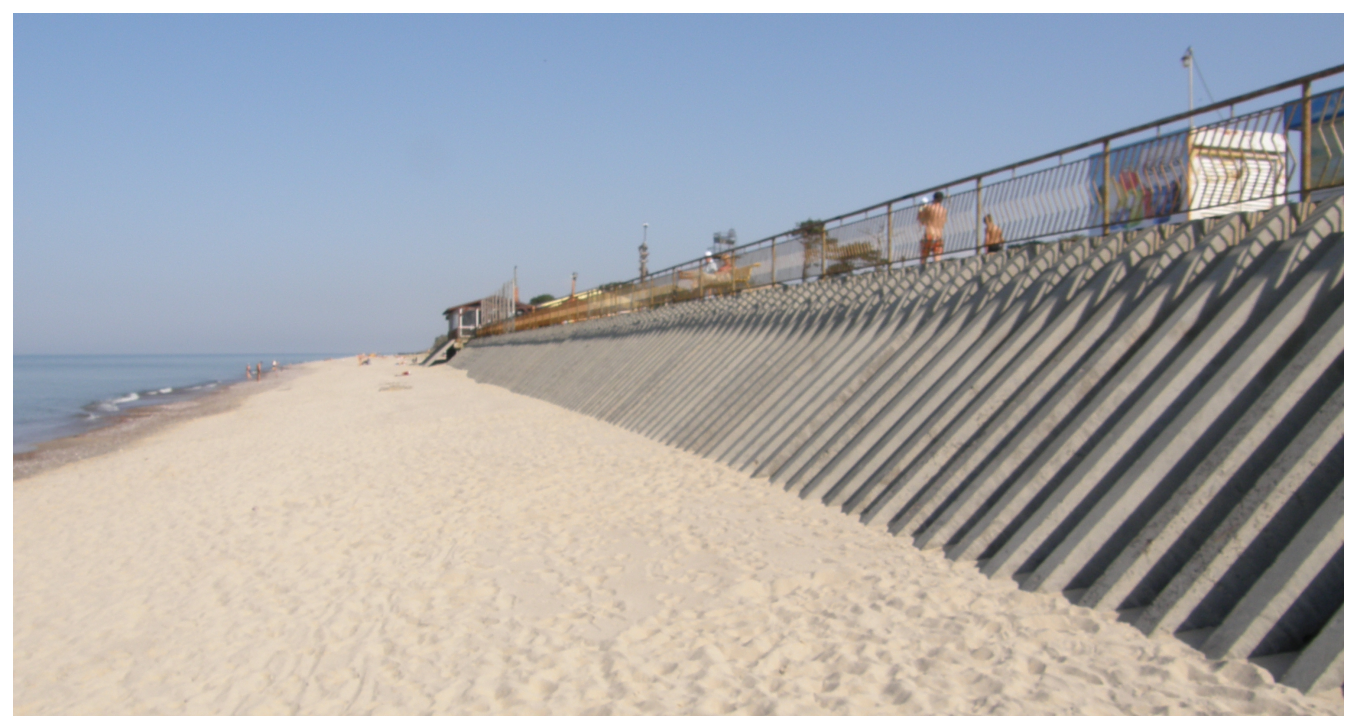

Fig. 11. A massive permeable revetment with pavement on top in Lesnoy, built in 1995

border. The most intensive accumulation is observed at the tip of the Curonian Spit, at the southern breakwater of the Klaipeda harbour. This combination of coastal processes is caused by the net longshore sediment flux directed to the north-east and north (Gulbinskas, Žaromskis 2010) being blocked to a large extent by the Klaipeda breakwaters (anthropogenic impact), as well as the shoreline azimuth changing from about $45^{\circ}$ near Lesnoy to about $0^{\circ}$ in Klaipeda (natural factors). According to Boldyrev (1999), the net longshore sand transport rate is the highest at the Curonian Spit root, amounting to about $250000 \mathrm{~m}^{3} /$ year.

Large and very high, locally mobile dunes are characteristic forms on the Curonian Spit. According to our field observations, their uncontrolled movement causes some problems, so light wooden structures are built to stabilise sand and mitigate undesirable aeolian processes (Fig. 12).

\section{Klaipeda northern breakwater - Lithuanian-Latvian border (region 5)}

The remaining part of the Lithuanian coast, from Klaipeda to the border with Latvia, is dominated by dune-beach shores, built of fine sands having a median grain diameter of $0.1-0.2 \mathrm{~mm}$. Longshore sediment transport is directed to the north and has a rate of about $150000 \mathrm{~m}^{3} /$ year. According to Dubra et al (2011), analyses of the dynamics of this "mainland" Lithuanian coast yield various results. In the period from 1993 to 2003, for instance, the mainland Lithuanian shore segment was reported to lose annually $48000 \mathrm{~m}^{3}$. According to another study discussed by Dubra et al (2011), the mainland Lithuanian beaches accumulated $100000 \mathrm{~m}^{3}$ a year.

Breakwaters shielding the entrance to the Klaipeda harbour and the Curonian Lagoon have significant influence on local morphodynamics (anthropogenic impact). 


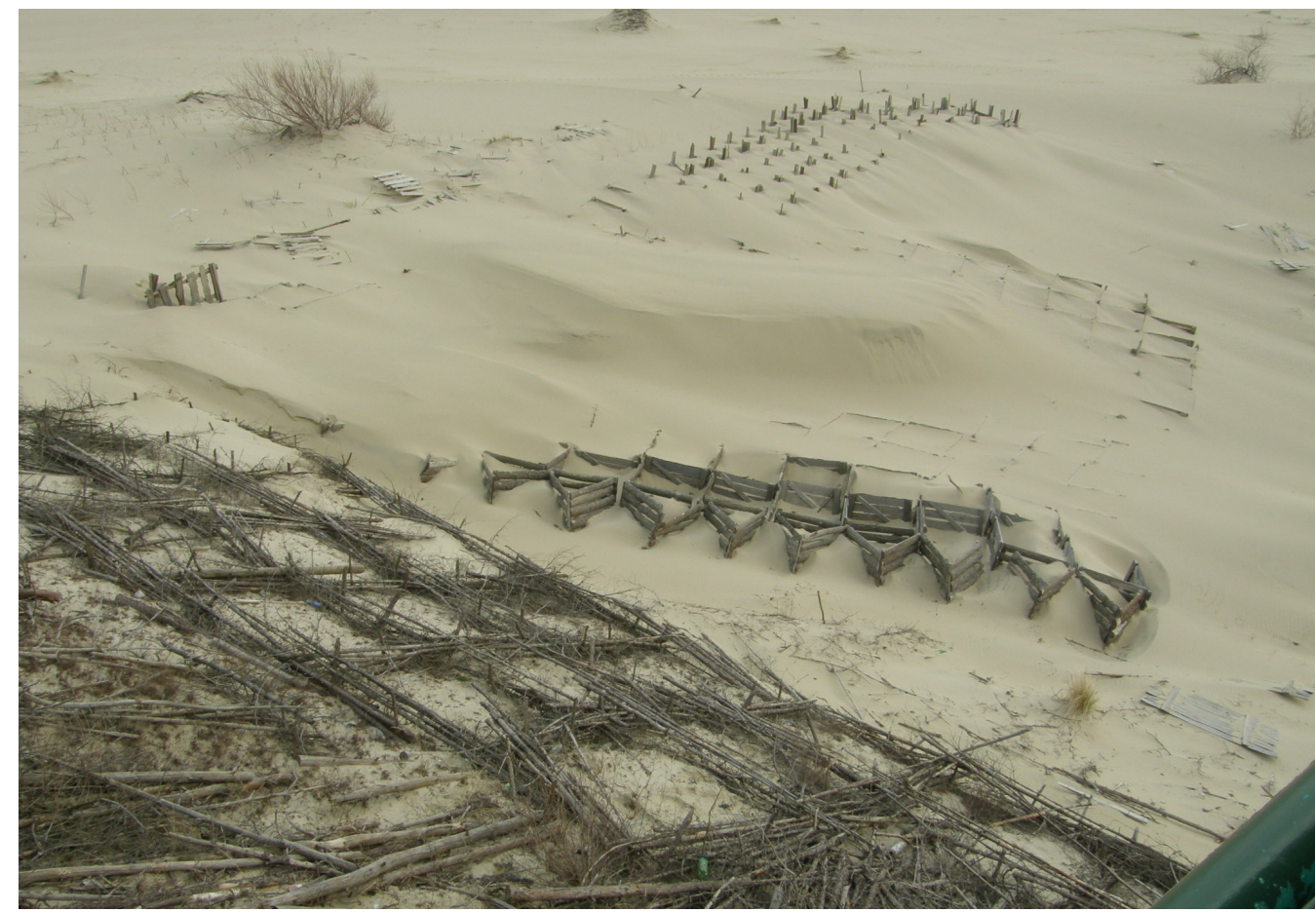

Fig. 12. Stabilisation of quicksand on the Curonian Spit

Owing to the very intensive longshore sediment transport, the disturbance caused by the breakwaters results in lee-side erosion on the shores north of Klaipeda, namely at Giruliai and Karkle. The erosive area stretches as far as the town of Palanga, situated $24 \mathrm{~km}$ from Klaipeda. Palanga is the largest seaside resort in Lithuania and attracts numerous tourists every summer. Therefore, a wide beach seems absolutely necessary for the successful functioning and development of this town. The shore in Palanga was relatively stable until the 1980s, but in the 1990s, after the modernisation and extension of the breakwaters in Klaipeda, the region of Palanga started to suffer from increasingly severe shore erosion, which was probably also due to greater storminess.

In 2006, the Lithuanian authorities implemented artificial beach nourishment on a $2.7 \mathrm{~km}$ long shore segment in Palanga. Since then, nourishment operations have periodically been repeated. The volumes of nourishment in 2006 and 2008 amounted to $40000 \mathrm{~m}^{3}$ and $120000 \mathrm{~m}^{3}$, respectively. Re-nourishment in 2011 again made use of $120000 \mathrm{~m}^{3}$, and a beach fill in 2012 was carried out with $290000 \mathrm{~m}^{3}$ (Gulbinskas, personal communication, 2012). The above figures indicate that, in total, $570000 \mathrm{~m}^{3}$ of sand was placed on the Palanga beach. The shore was nourished with coarser sand $\left(d_{50} \approx 0.45 \mathrm{~mm}\right)$ than the native sediment occurring in Palanga $\left(d_{50} \approx 0.17 \mathrm{~mm}\right)$. The borrow area was located at a depth of 20-25 m (10-15 km from the Curonian Spit shoreline), about $60 \mathrm{~km}$ south-south-west of Palanga. The sediment was transported 
to Palanga by a hopper dredger and moved to the beach as a water-soil mixture by a $1.5 \mathrm{~km}$ long pipeline lying on the sea bed. As a result, the two-bar system of the nearshore zone has been restored. At present (autumn 2012), the beach in Palanga is about $75 \mathrm{~m}$ wide.

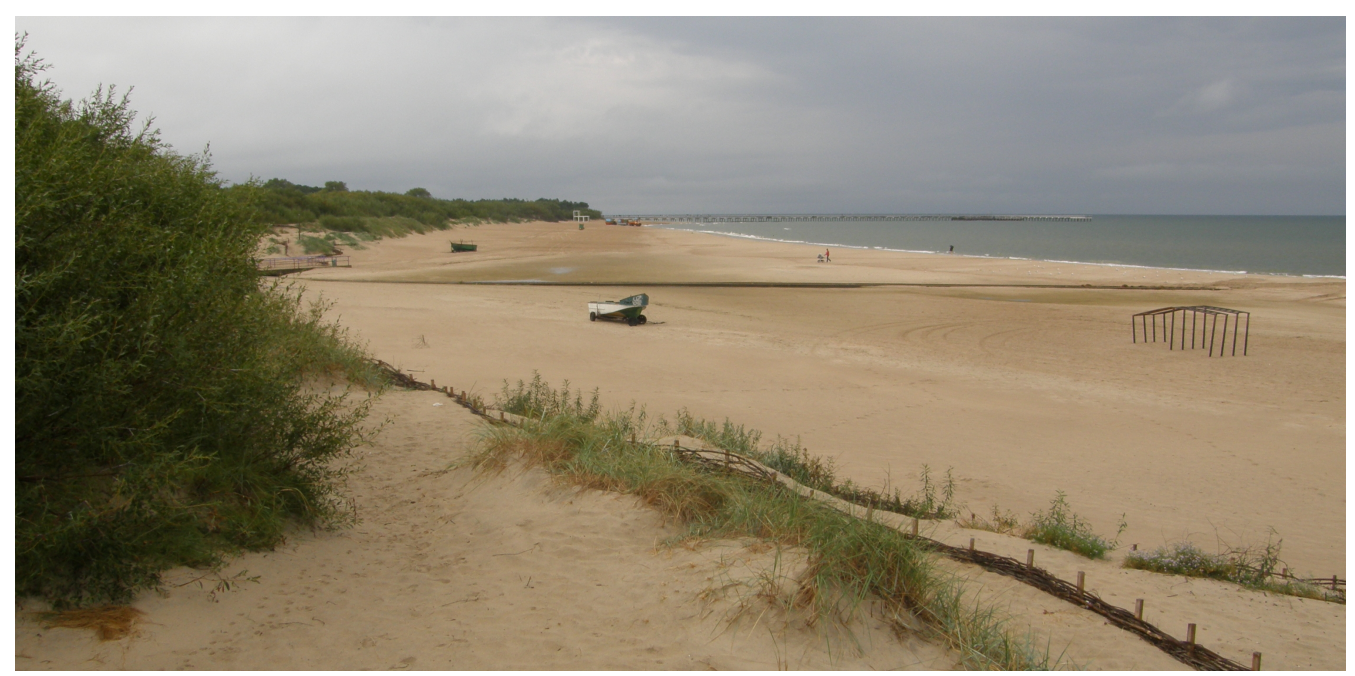

Fig. 13. Results of artificial shore nourishment in Palanga (September 2012)

The shores north of Palanga seem relatively stable: accumulation predominates, but there are also some erosive sites (with a mean abrasion rate of less than $1 \mathrm{~m} /$ year). No shore protection measures are applied in this shore segment.

A small harbour of Sventoji, located about $12 \mathrm{~km}$ north of Palanga $(36 \mathrm{~km}$ from Klaipeda), is an obstacle for longshore sediment transport. Old breakwaters do not function properly, but the remnants of the palisade-stone structure disturb the littoral drift and cause sand accumulation south of the breakwater system (our field observations in the autumn of 2012). The breakwaters in Sventoji are reportedly too short to prevent the harbour entrance from silting up (Fig. 14). Hence, the access to a new marina is very limited.

Shore erosion is observed between Sventoji and the Lithuanian-Latvian border. No coastal defence measures have been applied there.

\section{Discussion}

Most of the south-eastern Baltic coast is subject to erosive processes, resulting from complex and variable natural factors (multiple changes in shore exposure to the predominating wave energy flux), as well as anthropogenic effects (entrances to two large harbours, a wide artificial river outlet and the discharge of vast sediment volumes). Erosion is particularly evident on the Sambia Peninsula, where the shores east of the 


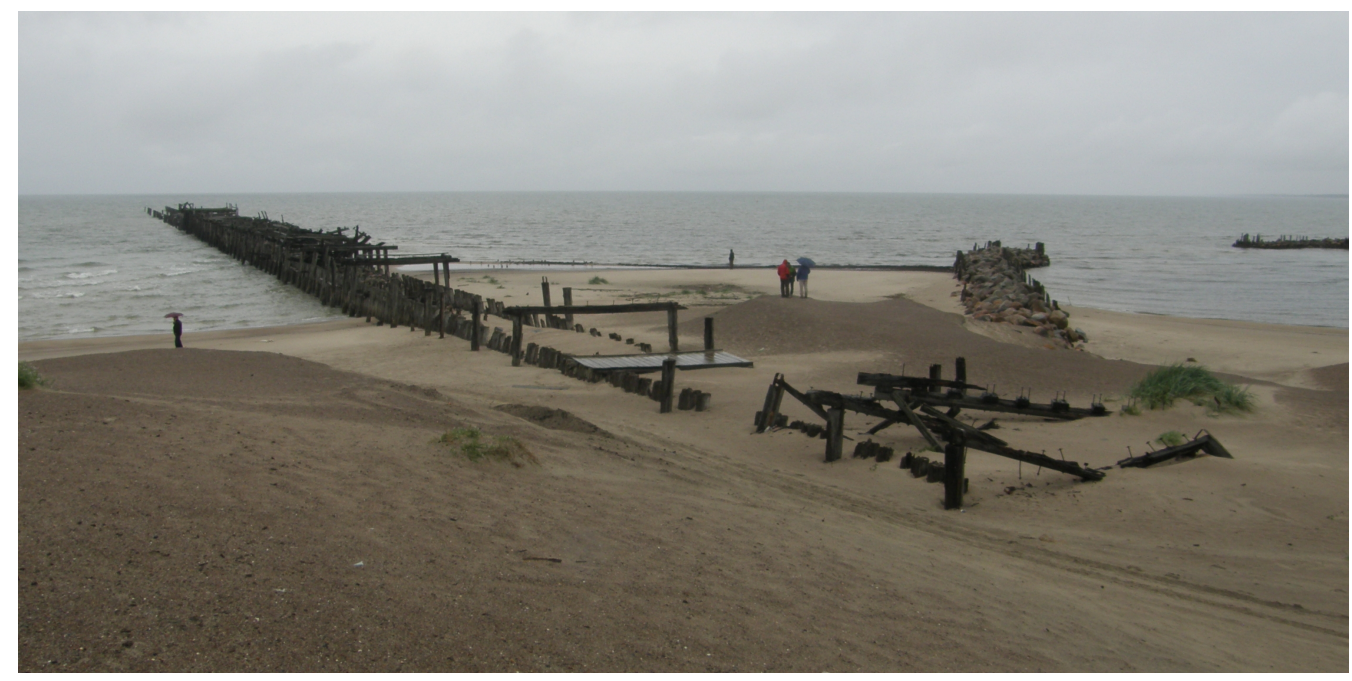

Fig. 14. Old harbour breakwaters in Sventoji, built in the 1920s and 1930s

Cape Taran (where sediment fluxes diverge) are abraded continuously at a rate of almost $1 \mathrm{~m} /$ year, while the shores south of the Cape Taran are returning to their natural erosive character, temporarily altered by the amber mining plant near Yantarnyy after 1880. The functioning of the plant led to the nearshore accumulation of sediments, especially from 1958 to 1989 . As a result of the recent significant reduction of sandy discharges from the amber mining plant, the erosion of the western Sambian coast has resumed, and its present rate amounts to several metres per year. Nevertheless, the previously accumulated sandy waste still constitutes an enormous reserve of sand on the shores between Yantarnyy and the Baltiysk Strait.

The shores of the Curonian Spit and the Vistula Spit are predominantly accumulative (convergence of sediment fluxes near the Vistula Spit root), except for the root part of the Curonian Spit and the end part of the Vistula Spit. The Lithuanian shores north of Klaipeda are in some segments distinctly erosive (Giruliai-Karkle, Palanga), stable or even slightly accumulative (near Sventoji). The erosion of shore segments north of Klaipeda and south-west of Baltiysk is definitely related to the presence of breakwater structures in the nearby harbours, which considerably disrupts longshore sediment fluxes. The directions of the net longshore sediment transport in the study area, together with the morphological types of shores, are given in Fig. 15.

Shore protection in the south-eastern Baltic Sea area under analysis is undertaken mainly along coastal segments adjacent to towns and villages of tourist interest, such as those near Svetlogorsk, Pionerskiy, Zelenogradsk and Lesnoy in Russia (Kaliningrad Oblast) and at Palanga in Lithuania. The Russian shores are protected mostly by old and ineffective timber single-palisade groins built before the Second World War, currently damaged and malfunctioning. New groins have not been constructed. Gabion revetments or permeable concrete revetments with pavement on top have been 


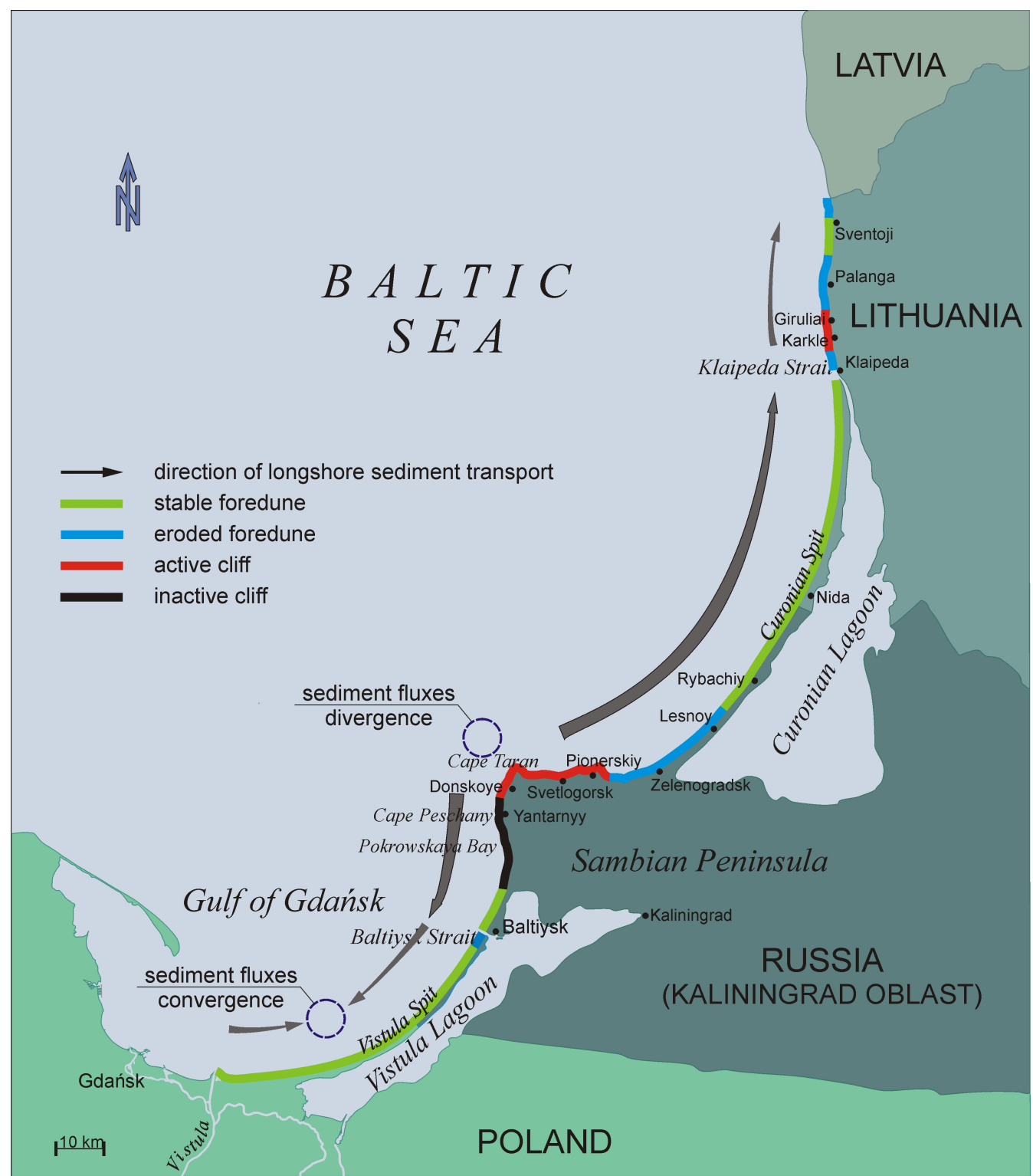

Fig. 15. Longshore sediment transport directions and morphological types of shores in the study area

built in recent decades in the Russian part of the south-eastern Baltic Sea. These structures cause heavy beach erosion due to the exposure of shores to the resultant wave energy, so that artificial nourishment with sand is necessary to maintain the sea shore. Beach erosion in Palanga is mitigated by intensive artificial shore nourishment.

Consisting mostly of systems of high and large dunes, the shores of the Curonian Spit and of the Vistula Spit, with the convergence point of sediment fluxes near its root, 
are relatively stable in terms of long-term morphodynamics, despite aeolian processes causing the uncontrolled motion of sand. In order to stabilise this quicksand, wooden fences and other light small structures are placed in dune areas. In addition, selected species of grasses and bushes are planted on the dunes to counteract undesirable aeolian phenomena.

On the basis of results obtained from the theoretical model and their interpretation in the light of field investigations, it can be concluded that van Rijn's (1993) approach is a useful tool for describing complex coastal lithodynamic processes, even in large time and spatial scales.

\section{Acknowledgements}

The study was sponsored by the Ministry of Science and Higher Education, Poland, under the IBW PAN mission-related programme No. 2 and by the Russian Academy of Sciences, as part of mission-related research carried out at the AB IO RAS. The authors also acknowledge the joint research project Development of the scientific basis for shore protection of the South Baltic coast conducted in 2011-2013 by the IBW PAN and the AB IO RAS under the Agreement on Scientific Cooperation between the Polish Academy of Sciences and the Russian Academy of Sciences.

\section{References}

Babakov A. (2003) Spatial-temporal structure of currents and sediment motion in the south-east Baltic coastal zone (Sambia Peninsula and Curonian Spit), PhD thesis, State University in Kaliningrad, Dept. of Geography, 273 pp. (in Russian).

Babakov A. (2010) Wind-Driven Currents and their Impact on the Morpho-Lithology at the Eastern Shore of the Gulf of Gdańsk, Archives of Hydro-Engineering and Environmental Mechanics, 57 (2), 85-104.

Babakov A., Chubarenko B., Ostrowski R. and Pruszak Z. (2010) Variability of characteristics of coastal sediments on the natural shore and the shore adjacent to harbour structures, Inżynieria Morska $i$ Geotechnika, 3, 409-416 (in Polish).

Bass O. and Zhindarev L. (2007) Technogenesis in the coastal zone of sandy shores of inland sea, Geomorphology, 4, 17-24 (in Russian).

Battjes J. A. and Janssen J. P. F. M. (1978) Energy loss and set-up due to breaking of random waves, Proc. 16th ICCE, Vol. I, 569-587.

Bobykina W. and Karmanov K. (2009) Dynamics of the Gulf of Gdańsk shores and its relation with anthropogenic effects, Proceedings of the International Conference "Sense and use of artificial earth plots in water basins and on their shores", Novorossiysk, 20-25 July 2009, 119-124 (in Russian).

Boldyrev V. L., Lazshenkov V. M. and Rjabkova O. I. (1992) Evolution of western coast Kaliningrad region. Evolution of coast in the conditions of a raising of ocean level, Moscow, 212-225 (in Russian).

Boldyrev V. (1999) Morphodynamic changes in the coastal zone of the Kaliningrad coast in connection with mass dumping of pulp in the Sea, Abstracts of the XXX Conference at the Kaliningrad State University, 44-46 (in Russian). 
Burnashov E., Chubarenko B. and Stont Z. (2010) Natural evolution of western shore of the Sambian Peninsula on completion of dumping from an amber mining plant, Archives of Hydro-Engineering and Environmental Mechanics, 57 (2), 105-117.

Burnashov E. M. (2011) Contemporary dynamics and geoecological condition of the Kaliningrad Oblast coast, PhD thesis, Barnaul - Siberian Branch of the Institute of Water and Ecological Problems of the Russian Academy of Sciences, 205 pp. (in Russian).

Chechko V. A., Chubarenko B. V., Boldyrev V. L., Bobykina V. P., Kurchenko V. Yu. and Domnin D. A. (2008) Dynamics of the marine coastal zone of the sea near the entrance moles of the Kaliningrad seaway channel, Water Resources, 35 (6), 652-661.

Dubra V., Grecevicius P. and Dubra J. (2011) Current changes of sandy seashore of Lithuania within the impact of natural and anthropogenic processes, Littoral 06006, EDP Science, 11.

Dubrawski R. and Zawadzka-Kahlau E. (2006) Future of protection of the Polish sea shores, Wyd. Instytutu Morskiego w Gdańsku, Gdańsk, 302 pp. (in Polish).

Gelumbauskaite L. (2003) On the morphogenesis and morphodynamics of the shallow zone off the Curonian Spit, Baltica, 16, 37-42.

Gulbinskas S. and Žaromskis R. (2010) Main patterns of coastal zone development of the Curonian Spit, Lithuania, Baltica, 23 (2), 149-156.

Gurova E. and Chubarenko B. (2012) Remote-sensing observations of coastal sub-mesoscale eddies in the South-Eastern Baltic, Oceanologia, 54 (4), 631-654.

Musielak S. (1980) Contemporary coastal processes in the Gulf of Gdańsk region, GTN, Gdańsk, Peribalticum, 1 (in Polish).

Orlenok V. V. (2004) Geomorphology and ecology of the south-east Baltic coast. Problems related to its protection, conservation and management. Coastal zone: Morphology and geoecology, Materials of XXI International Coastal Conf., Svetlogorsk, Russia, 7-10.09.2004, KGU, 7-17 (in Russian).

Ostrowski R., Pruszak Z., Skaja M. and Szmytkiewicz M. (2010) Variability of Hydrodynamic and Lithodynamic Coastal Processes in the East Part of the Gulf of Gdańsk, Archives of Hydro-Engineering and Environmental Mechanics, 57 (2), 139-153.

Ostrowski R., Pruszak Z., Babakov A. and Chubarenko B. (2012) Anthropogenic effects on coastal sediment fluxes in a non-tidal gulf system, J. Waterway, Port, Coastal, Ocean Eng., 138 (6), 491-500.

Sokolov A. and Chubarenko B. (2012) The wind influence on the near shore currents formation in the southern-eastern Baltic: numerical modelling results, Archives of Hydro-Engineering and Environmental Mechanics, 59 (1-2), 37-48.

Soomere T., Viška M. and Eelsalu M. (2013) Spatial variations of wave loads and closure depths along the coast of the eastern Baltic Sea, Estonian Journal of Engineering, 19 (2), 93-109.

Szmytkiewicz M. (1996) 2D velocity distributions in nearshore currents, Proc. Coastal Dynamics '95, ASCE, New York, 366-376.

Szmytkiewicz M. (2002a) Wave-induced currents in the coastal zone, IBW PAN Publishers, Gdańsk, ISBN 83-85708-45-6, 235 pp. (in Polish).

Szmytkiewicz M. (2002b) Quasi 3D model of wave-induced currents in coastal zone, Archives of Hydro-Engineering and Environmental Mechanics, 49 (1), 57-81.

Van Rijn L. C. (1993) Principles of sediment transport in rivers, estuaries and coastal seas, Aqua Publ., Amsterdam, 614 pp.

Zawadzka-Kahlau E. (1999) Developmental tendencies of the Polish south Baltic shores, Gdańskie Towarzystwo Naukowe, Gdańsk, 147 pp. (in Polish).

Zawadzka-Kahlau E. (2012) Morphodynamics of dune shores of the south Baltic, Wydawnictwo Uniwersytetu Gdańskiego, Gdańsk, 353 pp. (in Polish). 